\title{
Ocena poziomu zrozumienia zasad lean management przez pracowników linii produkcyjnych i montażowych
}

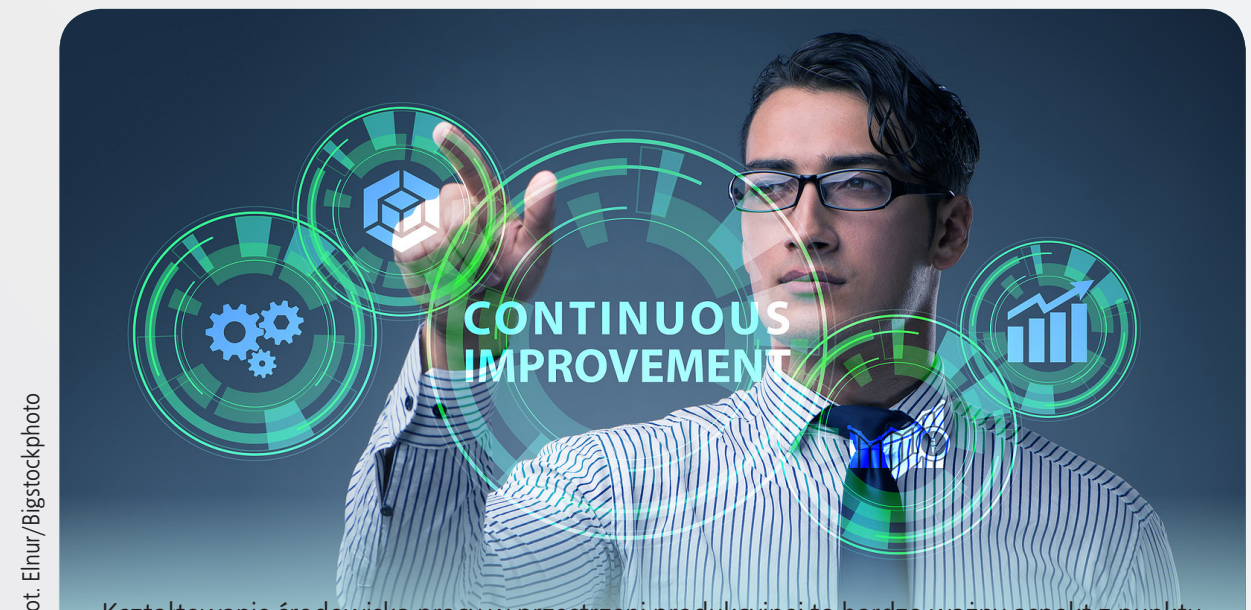

Kształtowanie środowiska pracy w przestrzeni produkcyjnej to bardzo ważny aspekt z punktu widzenia zarówno bezpieczeństwa i higieny pracy, jak i efektywności czy ciągłości procesów produkcyjnych. Modelowanie warunków na stanowisku pracy odnosi się przede wszystkim do przestrzegania zapisów prawnych i minimalizowania oddziaływania różnych czynników na pracownika. W świetle nowoczesnych technik zarządzania pełen pakiet rozwiązań do doskonalenia środowiska pracy zawiera koncepcja lean management, wspierana przez narzędzia, metody i koncepcje, takie jak: metoda 5S, kaizen czy ciągłe doskonalenie. W artykule przedstawiono wyniki badań mających na celu określenie poziomu zrozumienia podstawowych zasad lean management przez pracowników przedsiębiorstw produkcyjnych.

Słowa kluczowe: doskonalenie, praktyki5s, lean management, środowisko pracy, optymalizacja procesów

Evaluation of the comprehension level of lean management by production and assembly line workers

Shaping the working environment in the production space is a very important aspect both from the point of view of occupational health and safety, as well as efficiency and production processes continuity. Modeling conditions at the workplace relates primarily to compliance with legal provisions and minimizing the impact of various factors on the employee. In the light of modern management techniques, the full package of solutions for improving the work environment inc ludes the concept of lean management supported by tools, methods and concepts, such as the $5 S$ method, kaizen, continuous improvement. This paper presents the results of research aimed at determining the level of the lean management basic principles understanding by employees from manufacturing companies.

Keywords: improvement, 55 practices, lean management, work environment, process optimization

\section{Wstęp}

Jak wynika z definicji, środowisko pracy jest zespołem czynników materialnych i społecznych, z którymi pracownik pozostaje w bezpośrednim kontakcie podczas wykonywania wszelkich czyn- ności zawodowych, a z punktu widzenia zarządzania bezpieczeństwem i higieną pracy - zestawem czynników stanowiących potencjalne zagrożenie dla zdrowia i życia człowieka. Samo kształtowanie środowiska sprowadza się do przestrze- gania zapisów prawnych oraz minimalizowania oddziaływania na pracownika czynników zagrożenia: fizycznych, chemicznych, biologicznych i psychofizycznych [1-3]. Dominującym aspektem kształtowania środowiska pracy w odniesieniu do zarządzania bezpieczeństwem i higieną pracy są ludzkie potrzeby i możliwości. Natomiast z perspektywy zarządzania produkcją (czy inżynierii produkcji) środowisko pracy tworzą głównie: układ czynników materialnych, z którymi pracownik pozostaje w interakcji, oraz zestaw operacji (działań) wynikających z przebiegu procesu biznesowego. Kluczowe w kształtowaniu środowiska pracy w odniesieniu do zarządzania produkcją są techniczne i technologiczne możliwości realizacji procesów [3-7]. Celem artykułu jest prezentacja wyników badań, na podstawie których przeprowadzono ocenę poziomu zrozumienia zasad lean management w przedsiębiorstwach produkcyjnych w aspekcie stosowania narzędzi lean wspomagających zarządzanie bezpieczeństwem.

\section{Lean management}

Przedsiębiorstwa, które należycie dbają o bezpieczeństwo pracowników, a jednocześnie dążą do zwiększenia efektywności swoich procesów, starają się spełnić nawet najbardziej wygórowane standardy jakości i bezpieczeństwa - zazwyczaj przez wdrażanie nowoczesnych technik zarządzania, takich jak lean management.

Lean management to koncepcja zarządzania przedsiębiorstwem, oparta na zasadach zaczerpniętych z systemu produkcyjnego Toyoty (Toyota Production System - TPS) [8]. Jej istotą jest wprowadzenie przekształceń - zarówno organizacyjnych, jak i funkcjonalnych - które sprzyjają powolnemu, ale ciągłemu dążeniu do doskonałości, rozumianej jako umiejętność maksymalizacji wykorzystania środków z zachowaniem wymaganego poziomu jakości. Wdrożenie w przedsiębiorstwie koncepcji lean wiąże się jednak z koniecznością wprowadzenia licznych zmian w jego funkcjonowaniu. Generalnie te zmiany nie odnoszą się do ogólnych zasad funkcjonowania firmy, lecz do uelastycz nienia jej struktury organizacyjnej, zwiększenia transparentności wszystkich powiązań organizacyjnych oraz do zwiększenia nakładów na rozwój pracowników. Wszystkie działania lean w danym 


\begin{tabular}{|c|c|c|c|c|c|c|c|}
\hline $\mathbf{T}$ & $\mid$ & $\mathbf{M}$ & $\mathbf{W}$ & 0 & 0 & D & $S$ \\
\hline Transport & Inventory & Motion & Waiting & Overprocessing & Overproduction & Defects & Staff/skills \\
\hline $\begin{array}{l}\text { Niepotrzebny } \\
\text { transport }\end{array}$ & $\begin{array}{c}\text { Nadmierne } \\
\text { magazynowanie }\end{array}$ & $\begin{array}{l}\text { Zbędne } \\
\text { ruchy }\end{array}$ & $\begin{array}{c}\text { Zbędne } \\
\text { wyczekiwanie }\end{array}$ & $\begin{array}{c}\text { Nadmierne } \\
\text { przetwarzanie }\end{array}$ & Nadprodukcja & $\begin{array}{c}\text { Defekty } \\
\text { (niezgodności) }\end{array}$ & $\begin{array}{c}\text { Niewykorzystany } \\
\text { potencjał } \\
\text { pracownika }\end{array}$ \\
\hline
\end{tabular}

Rys. Typy marnotrawstwa według zasad lean management (lean production)

Fig. Types of waste according to the principles of lean management (lean production)

przedsiębiorstwie powinny zmierzać do zidentyfikowania i zminimalizowania ośmiu typów marnotrawstwa: TIM WOODS (rys.).

W identyfikowaniu i ograniczaniu różnych rodzajów marnotrawstwa w przedsiębiorstwie pomocne są liczne narzędzia, metody i koncepcje przeznaczone do doskonalenia procesów. Wśród takich instrumentów należy wymienić przede wszystkim: mapowanie strumienia wartości (value stream mapping - VSM), cykl Deminga, nazywany też cyklem PDCA (Plan, Do, Check, Act), praktyki $5 S$ (sortowanie, systematyka, sprzątanie, standaryzacja, samodyscyplina), kaizen, JIT (just in time) kanban, SMED (single minute exchange of die), TPM (total productive maintenance), Poka-Yoke itd. [9-13].

\section{Doskonalenie procesów i bezpieczeństwo pracy}

Wyzwaniem dla obecnych przedsiębiorstw a zwłaszcza dla ich kadry zarządzającej, jest doskonalenie wszystkich obszarów działalności w sposób ciągły i równomierny. Wśród wielu roz wiązań doskonalenia firmy bardzo ważne miejsce zajmuje filozofia kaizen, której znaczenia można się doszukiwać w zmianach działań na poziomie organizacyjnym. Według jej zasad doskonalenie procesów powinno się odbywać małymi krokami przy ogólnej akceptacji i zaangażowaniu uczestników procesu. Wiąże się to z nieustannym aktywizo waniem pracowników organizacji do poszukiwania najbardziej optymalnych rozwiązań i tym samym - do eliminowania wszelkich błędów (problemów) w całym systemie. Według koncepcji kaizen w procesie doskonalenia ważne jest osiąganie łatwo do stępnych celów, co pozwala ograniczyć lęk przed radykalnymi zmianami, a jednocześnie gwarantuje dochodzenie do sukcesu w sposób powolny, ale skuteczny [14].

Z uwagi na bardzo duży udział człowieka we wszystkich działaniach doskonalących bez względnie konieczne są: podnoszenie kwalifikacji pracowników oraz poprawa systemów zarządzania pod względem bezpieczeństwa ludzi i stabilności procesów

Z punktu widzenia bezpieczeństwa i higieny pracy niezmiernie ważnym instrumentem doskonalenia jest metoda $5 S$ (nazywana również prak tykami 5S). Obejmuje ona zespół technik, dzięki którym utwierdzamy się w przekonaniu, że czyste komfortowe i schludne warunki pracy są podsta- wą zarządzania, odpowiedniego środowiska pracy i pozytywnego nastawienia, co w konsekwencji prowadzi do zamierzonych wyników i celów organizacji $[15,16]$.

W myśl koncepcji 5 S każde „S" oznacza przej ście kolejnego etapu na drodze do doskonałości. Jako podstawowe elementy tej metody należy wymienić: selekcję, systematykę, sprzątanie, standaryzację i samodyscyplinę. Warto zaznaczyć, że $5 S$ stanowi podstawę, która jest rozwijana o kolejne elementy (kolejne "S"). Metoda uwzględnia ścisłą konsekwencję działań (według schematu: selekcja, systematyka, sprzątanie, standaryzacja i samodyscyplina). Rozpoczyna się od przeprowadzenia selekcji rzeczy w obrębie pracy człowieka, co oznacza nadanie narzędziom i wszystkim elementom na stanowisku pracy rangi przydatności poprzez selekcję, a następnie sprzątanie i standaryzacje. W konsekwencji niepotrzebne przedmioty zostają usunięte ze stanowiska pracy, a te, które pozostały, zostają uporządkowane przez przypisanie im odpowiedniego koloru, kodu, numeru, miejsca (zgodnie z ergonomicznym działaniem w obszarze stanowiska pracy). Najtrudniejszy do osiągnięcia jest jednak poziom piąty - samodyscyplina. Założenie jest takie, że pracownik sam, bez mobilizowania go, będzie dbał o przestrzeganie standardów na stanowisku pracy. Dlatego właśnie po raz kolejny pojawia się konieczność rozwijania kompetencji pracowników w zakresie doskonalenia procesów i rozumienia zasad nowoczesnego zarządzania [15, 16].

\section{Obszar badawczy}

Celem badań ankietowych, przeprowadzonych wśród pracowników przedsiębiorstw produkcyj nych (głównie osób pracujących przy liniach produkcyjnych lub montażowych), było określenie poziomu zrozumienia zasad lean management w kontekście narzędzi wspierających, takich jak praktyki 5S, filozofia kaizen i ciągłe doskonalenie. W tym celu stworzono prosty kwestionariusz, który oprócz metryczki weryfikującej grupę ba dawczą zawierał tylko 10 pytań. Kwestionariusz miał formę ankiety elektronicznej (metoda CAWI) przeznaczonej wyłącznie dla pracowników tych podmiotów, które stosują zasady lean.

Do oceny stopnia akceptacji zjawiska lub po glądu na określony temat zastosowano pięciostopniową skalę Likerta, gdzie kolejne liczby oznaczały: 1 - zdecydowanie nie, 2 - raczej nie, 3 - nie mam zdania, 4 - raczej tak, 5 - zdecydowanie tak. W badaniu wzięło udział ponad 300 osób, ale tylko 99 z nich spełniało warunki (praca w przedsiębiorstwach produkcyjnych na stanowiskach produk cyjnych i montażowych oraz wskazanie lean jako koncepcji wdrożonej w przedsiębiorstwie); zaledwie 78 ankiet zostało wypełnionych w całości.

Rzetelność badania ankietowego potwierdzono testem Cronbach Alpha, którego wskaźnik wyniósł 0,861

Właściwa część kwestionariusza składała się z następujących pytań/stwierdzeń:

- P1. W przedsiębiorstwie, w którym pracuję, bezpieczeństwo pracowników jest bardzo ważne.

- P2. Poziom bezpieczeństwa mojego stanowiska pracy jest odpowiedni.

- P3. W przedsiębiorstwie, w którym pracuję, praktyki 5S są powszechnie stosowane.

- P4. Na moim stanowisku pracy są wdrożone i dobrze funkcjonują zasady 55 .

- P5. Po zakończonym dniu pracy starannie porządkuję moje stanowisko pracy.

- P6. Na moim stanowisku pracy często brakuje podstawowych narzędzi.

- P7. Stanowiska pracy na liniach produkcyjnych są kontrolowane pod względem uporządkowania.

- P8. Często zgłaszam pomysły w celu optymalizacji mojego stanowiska pracy.

- P9. Stanowiska pracy na liniach produkcyjnych są ciągle udoskonalane.

- P10.W przedsiębiorstwie, w którym pracuję, odpowiednio wykorzystywany jest potencjał człowieka.

\section{Wyniki badań i ich omówienie}

W celu oszacowania świadomości i znajomości zasad zarządzania lean oraz narzędzi wspomagających (praktyk 5S, filozofii kaizen i ciągłego doskonalenia), dokonano analizy korelacyjnej czynników

Alfa Cronbacha $(\alpha)$ - współczynnik rzetelności testów psychologicznych. Współczynnik ten został opisany po raz pierwszy przez Lee Cronbacha w pracy "Coefficient Alpha and the Internal Structure of Tests". Jest to najczę ściej używany w psychologii i badaniach edukacyjnych test badajacy rzetelność używanych kwestionariuszy, a konkretnie spójność wewnętrzną narzędzia. W psychologii uznaje się, że alfa Cronbacha narzędzia powinna wynosić co najmniej 0,60, a preferuje się, aby współ czynnik ten był zblizzony do 0,90 [przyp. red.]. 
Tabela. Macierz korelacji dla pytań/stwierdzeń z kwestionariusza

Table. Correlation matrix of questions/statements from the questionnaire

\begin{tabular}{|c|c|c|c|c|c|c|c|c|c|c|}
\hline & P1 & P2 & P3 & P4 & P5 & P6 & P7 & P8 & P9 & P10 \\
\hline P1 & 1,00 & & & & & & & & & \\
\hline P2 & 0,80 & 1,00 & & & & & & & & \\
\hline P3 & 0,41 & 0,55 & 1,00 & & & & & & & \\
\hline P4 & 0,16 & 0,21 & 0,28 & 1,00 & & & & & & \\
\hline P5 & $-0,02$ & 0,18 & 0,61 & 0,38 & 1,00 & & & & & \\
\hline P6 & 0,00 & $-0,21$ & $-0,63$ & $-0,43$ & $-0,99$ & 1,00 & & & & \\
\hline P7 & $-0,04$ & 0,09 & 0,62 & 0,76 & 0,66 & $-0,67$ & 1,00 & & & \\
\hline P8 & 0,02 & $-0,29$ & $-0,17$ & 0,17 & $-0,30$ & 0,30 & 0,07 & 1,00 & & \\
\hline P9 & 0,01 & 0,18 & 0,65 & 0,39 & 0,93 & $-0,91$ & 0,67 & $-0,11$ & 1,00 & \\
\hline P10 & 0,40 & 0,54 & 0,51 & 0,78 & 0,63 & $-0,64$ & 0,68 & $-0,01$ & 0,71 & 1,00 \\
\hline
\end{tabular}

Źródło: Opracowanie własne

(P1-10). W tabeli zaprezentowano współczynniki korelacji dla poszczególnych par pytań. Współczynnik korelacji r przyjmuje wartość w zakresie od -1 do 1 zatem możemy mówić o korelacji ujemnej (-) lub dodatniej (+). Przyjęto, że współczynnik $r$ bliski wartości -1 lub 1 świadczy o korelacji silnej (istotnej), natomiast współczynnik rbliski wartości 0 - o korelacji słabej (nieistotnej). W tabeli kolorem żółtym zaznaczono korelacje silne dodatnie (+), a kolorem jasnozielonym - korelacje silne ujemne (-).

Z zaprezentowanych danych wynika, że pięć najsilniejszych oddziaływań dodatnich wykazują pary pytań/stwierdzeń:

- P5 i P9 (Po zakończonym dniu pracy starannie porządkuję moje stanowisko pracy/Stanowiska pracy na liniach produkcyjnych są ciągle udoskonalane) $-r=0,93$. To oznacza, że wraz ze wzrostem dbałości pracowników o ich stanowiska pracy zwiększa się chęć dążenia do doskonałości.

- P1 i P2 (W przedsiębiorstwie, w którym pracuję, bezpieczeństwo pracowników jest bardzo ważne/Poziom bezpieczeństwa mojego stanowiska pracy jest odpowiedni) $-r=0,80$. To oznacza, że wraz ze wzrostem poszanowania dla bezpieczeństwa pracowników zwiększa się poczucie bezpieczeństwa na poszczególnych stanowiskach pracy.

- P4 i P10 (Na moim stanowisku pracy są wdro żone i dobrze funkcjonują zasady 5S/W przedsiębiorstwie, w którym pracuję, odpowiednio wykorzystywany jest potencjał człowieka) $r=0,78$, oraz P9 P10 (Stanowiska pracy na liniach produkcyjnych są ciągle udoskonalane/W przedsiębiorstwie, w którym pracuję, odpowiednio wykorzystywany jest potencjał człowieka) $r=0,71$. Świadczy to o tym, że wdrożenie i utrzymywanie zasad $5 S$ na stanowisku pracy sprzyja poczuciu wykorzystania potencjału pracowników. Ciągłe doskonalenie stanowisk pracy wzrasta ze stopniem spożytkowania kompetencji pracowników. Ci zaś, którzy zgłaszają swoje propozycje kaizen w odniesieniu do stanowiska pracy, są doceniani, co dodatkowo motywuje do przestrzegania zasad 5S. Innym czynnikiem, którego oddziaływanie jest widoczne w kwestii utrzymania porządku na stanowisku pracy, są regularne kontrole czystości.

- P4 i P7 (Na moim stanowisku pracy są wdrożone i dobrze funkcjonują zasady 5S/Stanowiska pracy na liniach produkcyjnych są kontrolowane pod względem uporządkowania) $-r=0,76$. To oznacza, że wraz ze wzrostem poziomu kontroli czystości stanowisk pracy wzrasta również akceptowalność i wykonalność zasad 5S.

Jednocześnie zauważono, że pięć najsilniejszych oddziaływań ujemnych wykazują pary pytań/stwierdzeń:

- P5 i P6 (Po zakończonym dniu pracy starannie porządkuję moje stanowisko pracy/Na moim stanowisku pracy często brakuje podstawowych narzędzi) $-r=-0,99$

- P9 i P6 (Stanowiska pracy na liniach produkcyjnych są ciągle udoskonalane/Na moim stanowisku pracy często brakuje podstawowych narzędzi) $-r=-0,91$

- P7 i P6 (Stanowiska pracy na liniach produkcyjnych są kontrolowane pod względem uporządkowania/Na moim stanowisku pracy często brakuje podstawowych narzędzi) $-r=-0,67$

- P10 i P6 (W przedsiębiorstwie, w którym pracuję, odpowiednio wykorzystywany jest potencjał człowieka/Na moim stanowisku pracy często brakuje podstawowych narzędzi) $-r=-0,64$

- P3 i P6 (W przedsiębiorstwie, w którym pracuję, praktyki 5S są powszechnie stosowane/ Na moim stanowisku pracy często brakuje podstawowych narzędzi) $-r=-0,64$.
Silne korelacje ujemne wskazują, że pracownicy, którzy jawnie zaniedbują codzienne obowiązki porządkowania swojego stanowiska pracy, często stwierdzają na nim braki narzędzi, elementów. W tym przypadku brak narzędzi jest oczywistą konsekwencją zaniechań pracowników. Prezentowane wyniki wskazują również na niski poziom zaangażowania pracowników w realizowanie założeń praktyk $5 S$ oraz koncepcji kaizen i ciągłego doskonalenia. Może to być spowodowane brakiem odpowiednich szkoleń, motywacji idziałań w tym zakresie, o czym świadczy również fakt, że pracownicy mają poczucie, że ich potencjał nie jest odpowiednio wykorzystywany. Zgodnie z ogólnymi założeniami nowoczesnych technik zarządzania (np. według założeń Toyoty) pracownik utożsamia się z przedsiębiorstwem i nie wymaga stałego nadzoru, aby właściwie wykonywać swoje obowiązki. Niestety, nie znalazło to potwierdzenia w niniejszych badaniach, z których wynika, że dopiero regularne kontrole poprawiają dbałość o stanowisko pracy oraz realizowanie zadań wynikających z praktyk 55 .

Pozostałe korelacje z punktu widzenia przeprowadzonej analizy wydają się nieistotne. Uzyskane wyniki wskazują zatem, że pomimo dużego zaangażowania przedsiębiorstwa we wdrażanie technik optymalizacji pracy - m.in. w celu poprawy bezpieczeństwa - pracownicy nadal nie rozumieją ogólnych przesłanek stosowanych technik (praktyki 5S, filozofii kaizen i ciągłego doskonalenia).

\section{Podsumowanie}

W artykule podjęto próbę oszacowania poziomu zrozumienia przez pracowników pracujących przy liniach produkcyjnych lub montażowych zasad lean management $w$ kontekście narzędzi wspierających, takich jak: praktyki 5S, filozofia kaizen 
i ciągłe doskonalenie. Na podstawie przeprowadzonych badań stwierdzono, że:

- wraz ze wzrostem dbałości pracowników o ich stanowiska pracy zwiększa się chęć dążenia do doskonałości

- wraz ze wzrostem poszanowania dla bezpieczeństwa pracowników zwiększa się poczucie bezpieczeństwa na poszczególnych stanowiskach pracy

- wdrożenie i utrzymywanie zasad 55 na stanowisku pracy sprzyja poczuciu wykorzystania potencjału pracowników

- wraz ze wzrostem poziomu kontroli czystości stanowisk pracy wzrasta również akceptowalność i wykonalność zasad 55.

\section{BIBLIOGRAFIA}

[1] NICIEJEWSKA, M., KIRILIUK, O. Occupational health and safety management in "small size" enterprises, with particular emphasis on hazards identification. Production Engineering Archives. 2020, 26(4): 195-201, doi: 10.30657/pea.2020.26.34.

[2] KLIMECKA-TATAR, D., Niciejewska, m. Small-sized enterprises management in the aspect of organizational culture. Revista Gestão \& Tecnologia. 2021, 21(1): 4-24, doi: 10.20397/2177-6652/2021. V2111.2023.

[3] PAGÁN-CASTAÑO, E., MASEDA-MORENO, A., SANTOS-ROJO, C. Wellbeing in work environments. Journal of Business Research. 2020, 115(1): 469-474, doi: 10.1016/j.jbusres.2019.12.007.

[4] PAPADOPOULOS, G., GEORGIADOU, P., PAPAZOGLOU, C., MICHALIOU, K. Occupational and public health and safety in a changing work environment: An integrated approach for risk assessment and prevention. Safety Science. 2010, 48(8): 943-949, doi: 10.1016/j.ssci.2009.11.002.

[5] KRUSE, T., VELTRI, A., BRANSCUM, A. Integrating safety, health and environmental management systems: A conceptual framework for achieving lean enterprise outcomes. Journal of Safety Research. 2019, 71:259-271, doi: 10.1016/j.jsr.2019.10.005.

[6] FíLA, O., et al. Safety and Automatization of Machining Line. System Safety: Human - Technical Facility - Environment. 2020, 2(1): 268-274, doi: 10.2478/czoto-2020-0033.

[7] SHANMUGASUNDAR, G., et al. Analysis of occupational health and safety measures of employee in material manufacturing industry using statistical methods. Materials Today: Proceedings. 2021, 451(1): 440, doi: 10.1016/j.matpr.2020.11.296.

[8] PALADUGU, BALA S.K., GRAU, D. Toyota Production System - Monitoring Construction Work Progress With Lean Principles. [In:] HASHMI S., CHOUDHURY I.A., eds. Encyclopedia of Renewable and Sustainable Materials. Vol 7. Elsevier, 2020, pp. 560-565, doi: 10.1016/ B978-0-12-803581-8.11512-7.

[9] SINGH, S., KUMAR, S. Review of literature of lean construction and lean tools using systematic literature review technique (2008-2018). Ain Shams Engineering Journal. 2020, 11(2): 465-471, doi: 10.1016/j.asej.2019.08.012.

[10] TORTORELLA, G., et al. Design of a methodology to incorporate Lean Manufacturing tools in risk management, to reduce work accidents at service companies. Procedia Computer Science. 2020, 177(4): 276-283, doi: 10.1016/j.procs.2020.10.038.

[11] VINOTHKUMAR, H., ANNAMALAI, S., BAGATHSINGH, N. Impact of lean implementation from the ergonomics view: A research article. Materials Today: Proceedings. 2020, 221(2016): 105, doi: 10.1016/j.matpr.2020.07.113.

[12] KLIMECKA-TATAR, D., INGALDI, M. How to indicate the areas for improvement in service process - the Knowledge Management and Value Stream Mapping as the crucial elements of the business approach. Revista Gestão \& Tecnologia. 2020, 20(2): 52-74, doi: 10.20397/2177-6652/2020. v20i2.1878.

[13] KLIMECKA-TATAR, D. Context of production engineering in management model of Value Stream Flow according to manufacturing industry. Production Engineering Archives. 2018, 21(21): 32-35, doi: 10.30657/pea.2018.21.07

[14] VAN SCYOC, K. Process safety improvement - quality and target zero. Journal of Hazardous Materials. 2008, 159(1): 42-48, doi: 10.1016/j. jhazmat.2008.02.036.

[15] PACANA, A. Metoda 5S. Częstochowa: Oficyna Wydawnicza Stowarzyszenia Menedżerów Jakości i Produkcji, 2016.

[16] SELEJDAK, J., KLIMECKA-TATAR, D., KNOP, K. Metoda 5S. Zastosowanie, wdrażanie i narzędzia wspomagające: Verlag Dashofer, 2012.

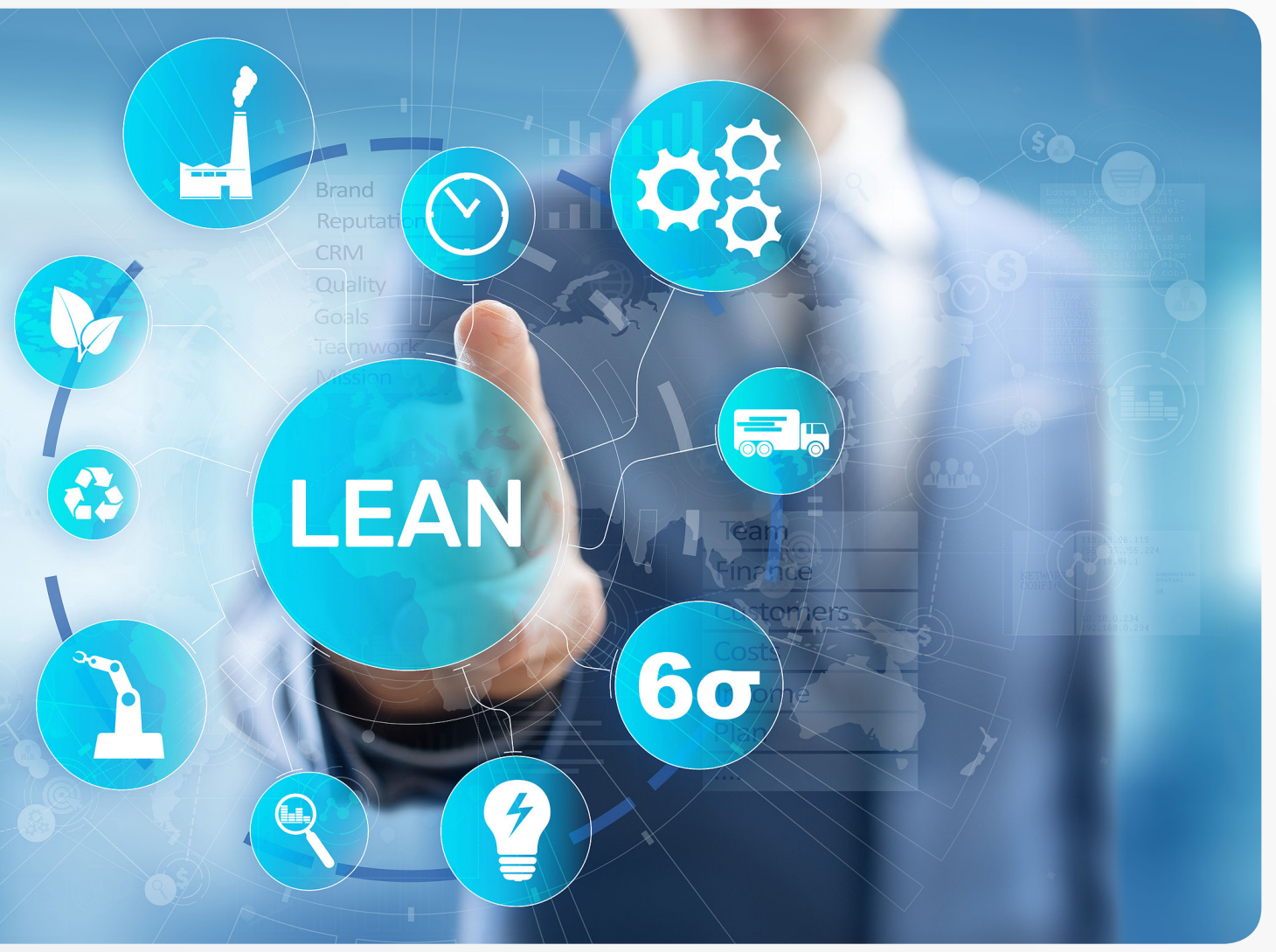

